\title{
South Africa ground zero for reforming drug patents
}

$\mathrm{T}$ he government of South Africa is squaring off against drug makers over patent reform in the lead-up to national elections on May 7, citing a "massive disease burden" from HIV/AIDS, tuberculosis, hepatitis, cancer and heart diseases.

At issue is a proposed national policy that would limit the number of pharmaceutical patents granted in the country and relax restrictions on sales of generic drugs, which the government says will cause prices to "fall drastically."

According to the Draft National Policy on Intellectual Property, issued last September and now being finalized before submission for Parliamentary ratification, the government aims to "adopt a common and united stand ... on improving access to medicines."

South Africa currently has no written intellectual property (IP) laws. As a result, unacceptably high numbers of patents are issued, according to the draft policy. South Africa uses a patent registration system that does not scientifically critique "newness," "obviousness," "novelty" and "usefulness." In 2008, the country granted 2442 pharmaceutical patents, according to a 2011 analysis funded by the International Development Research Centre in Ottawa, Ontario. In comparison, Brazil granted only 278 pharmaceutical patents in the five years between 2003 and 2008.

Drug makers are not happy with government efforts to hasten the proposed patent reforms. The Innovative Medicines South Africa (IMSA), which represents 24 domestic and international drug developers, states that the government has allotted a "totally inadequate" period of time for consultations.

In a written response to the draft policy, IMSA states that the reforms are discriminatory, unfair and unconstitutional, and warns of "unforeseen negative consequences across all industrial sectors" that will result "in a loss of confidence in and damage to the South African economy."

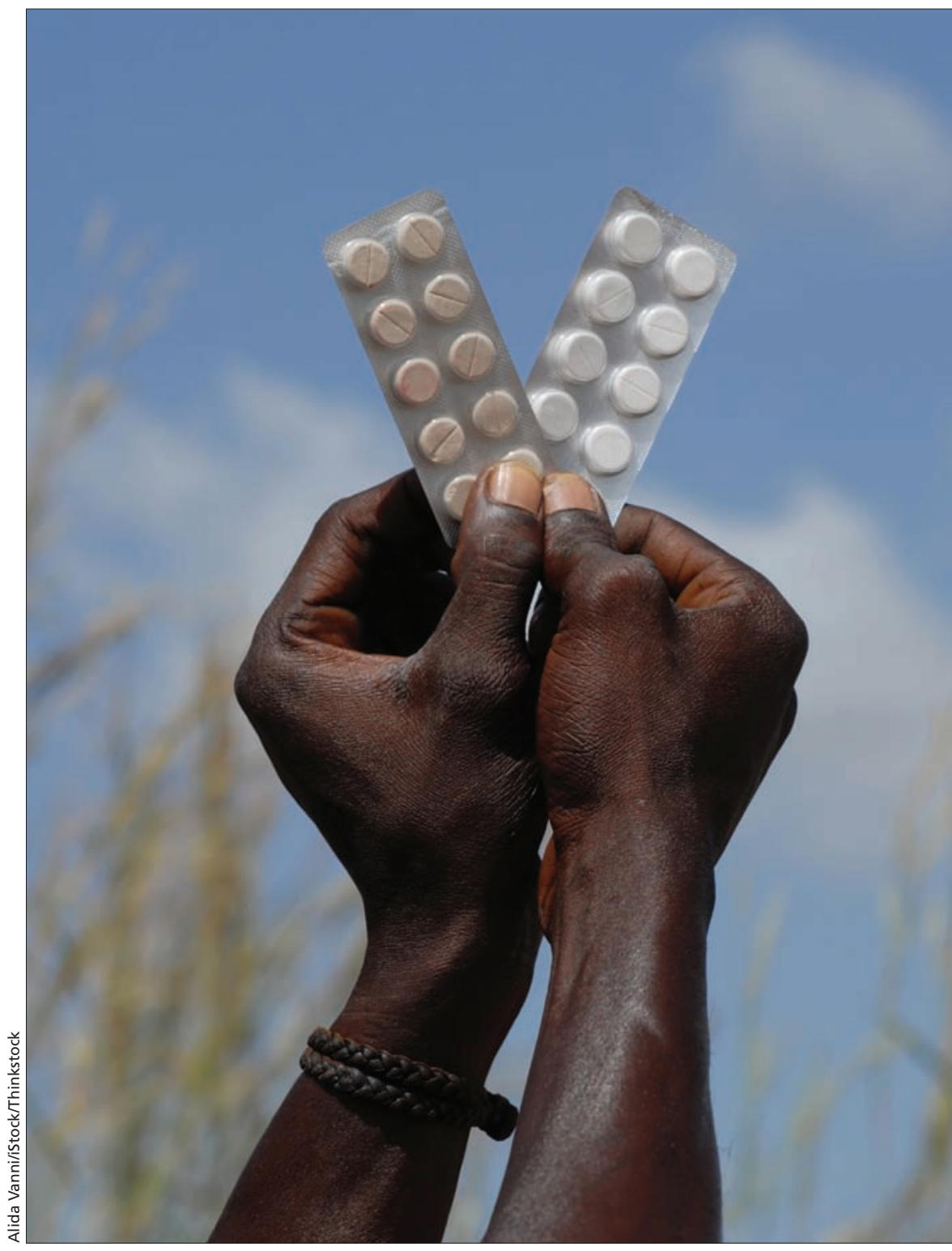

A proposed national policy would limit the number of pharmaceutical patents granted in South Africa and relax restrictions on sales of generic drugs, which the government says will cause prices to "fall drastically."

Private discussions about the proposed national policy within the industry appear even more heated. According to an industry lobbying plan obtained and circulated by the non-profit health aid organization, Médecins Sans Frontières, "South Africa is now ground zero for the debate on the value of strong IP protection. If the battle is lost here, the effects will resonate."
Not only will South Africa become "less hospitable to the Life Sciences sector," warns the plan, which was drafted for IMSA by Public Affairs Engagement, an Arlington, Virginiabased consulting firm, "it may also provide the model for other developing nations, inside and outside Africa, including such important aspiring economies as India and Brazil." 
The release of the proposed lobbying plan prompted Health Minister Aaron Motsoaledi to use a newspaper interview to accuse pharmaceutical companies of plotting a conspiracy of "satanic magnitude."

South Africa's government seems to appreciate the international implications of its push for flexibility in relaxing or rejecting drug patents. "South Africa should encourage other developing countries at international fora not to enter into bilateral trade agreements that undermine flexibilities," the draft national policy states.

Jillian Clare Kohler, a specialist in IP rights and the international pharmaceutical industry at the University of Toronto in Ontario, says the draft policy would bring South Africa in line with international norms.

"This is long overdue," she argues. "South Africa is waking up and looking at its domestic health needs and they now see noncommunicable diseases as a huge issue."

The industry's reaction is rooted in the fact that South Africa is the "hub for the pharmaceutical industry in Africa," adds Kohler. "This is a globalized industry. The industry gets nervous when this happens in any market."

A number of countries - including India, Thailand, Brazil, Malaysia, Zambia and Ecuador - have recently issued compulsory licences to overrule drug patents and improve access to medicines. In 2012, Indonesia issued a decree authorizing government use of patents for seven HIV/AIDS and hepatitis B medicines to allow local production of cheap generics.

Lotti Rutter, senior researcher with the Treatment Action Campaign, a Johannesburg-based group that successfully sued the South African government, forcing it to deliver universal drug treatment for HIV/AIDS in 2007, says implementation of the draft policy will help the government honour its health care commitments.

"As resistance to treatment develops, people living with HIV will be shifted from first-line regimens to much more expensive second- or even third-line regimens," she explains. Unless the government can take advantage of patent flexibilities, she warns "HIV-related costs are likely to rise sharply in the near future, restricting the success of the National Health Insurance scheme."

If the draft policy is implemented, Rutter predicts that public sector drug spending for a broad array of drugs will drop substantially. With the elections looming, she adds, "it's a very highprofile issue." - Paul Christopher Webster, Toronto, Ont.

CMAJ 2014. DOI:10.1503/cmaj.109-4752 